\title{
Obituary
}

Editor: Henry R. Rollin

Don Bannister, Professor, High Royds Hospital, Menston, Inkley, Yorkshire.

Don Bannister died on 11 July 1986 at the age of 58 . Only a few months earlier he learned that he had cancer and sadly, surgical treatment only offered a brief prolongation of his life.

He was born in a mining village in Yorkshire, where he demonstrated his intellectual ability by winning a place at a local grammer school. He graduated in Psychology from the University of Manchester in 1954, and completed his training as a Clinical Psychologist at the Maudsley Hospital three years later. In 1959, he wrote his thesis on Schizophrenic Thought Disorder which employed George Kelly's theory of Personal Construct to make sense of the apparent chaos of the schizophrenic's language and thought. Don's view of the role of clinical psychologists, which extended far beyond psychological testing and sought to establish psychologists as independent practitioners who had a valid and different approach to the treatment of psychological distress, was at variance with the Maudsley ethos; indeed, throughout his life many psychiatrists found his challenging approach to their cherished notions and medical roles distinctly uncomfortable. He left the Maudsley to head the department of Clinical Psychology at Bexley Hospital, where he pursued his research interests as a member of the MRC scientific staff.

Don was a passionate advocate of Kelly's ideas and methods, supporting his teaching both with his own research and also stimulating and encouraging his colleagues to apply Personal Construct Theory to their special areas of interest. He wrote the Evaluation of Personal Constructs with Miller Mair in 1968. Three years later he joined Fay Fransella to write Inquiring Man, still the best introductory account of Kelly's theory for lay and professional readers, and in 1977, again with Fay Fransella, he wrote a manual of repertory grid techniques, demonstrating the relevance of Kelly's ideas to the treatment of patients in a practical manner. He was a founder member of the Psychology and Psychotherapy Association, an organisation in which he was a tireless worker in many differing roles. In the late 1970s he left Bexley Hospital, moving to High Royds Hospital in his native Yorkshire, where he continued to work until his death.

Apart from his career as a research psychologist of international repute, his work as a clinical teacher and as a therapist, there are two other areas where Don showed outstanding ability. Firstly, as a politician and member of the Commonwealth Party and finally as a novelist. His first autobiographical novel, Sam Chard, received a glowing welcome from literary critics and it was followed by Long Day at Shiloh, an account of the battle which contains portraits of many colleagues in the guise of private soldiers. He wrote three more novels: Burning Leaves and the Summer $B o y$ and completing the fifth with Sharon Jackson shortly before he died.

Although not ambitious, he gained academic recognition, being visiting professor of Ohio University at George Kelly's invitation and visiting professor of Surrey University 1972-78 and at Brunel University from 1982 until his death. He achieved formal international recognition in 1984, with the award of a medal for his teaching and research by the University of Sienna.

He was a wise, humorous and inspiring man. A stalwart friend and colleague who sought pleasure in helping others to achieve their goals, whether patients, friends, research collaborators or joint authors. He organised innumerable workshops and conferences. For many of us the International Congress of PCP held in Cambridge will remain the last memory of seeing Don in action at his brilliant best.

Don had a challenging and witty way of communicating ideas and all those who knew him, whether as a lecturer, colleague or friend, grew as a result of that contact. We were all saddened by his passing but are profoundly glad to have known him.

MCB

Philip Pinkerton, Honorary Consultant Physician (Research), Department of Cystic Fibrosis, Brompton Hospital, London SW3.

Philip Pinkerton, a Foundation Fellow of the College, died at his home on 27 November 1986 after a long and distressing illness, borne with characteristic fortitude and spirit.

Philip qualified in 1944 at Edinburgh University, MB, $\mathrm{ChB}$, with honours and proceeded almost immediately to a successful and highly acclaimed career in paediatric psychiatry. He was awarded his MD (with Commendation) in 1956, having obtained the DPM, London, in 1949. For his MD thesis he explored the intimate relationship between psyche and soma, a subject which was to interest him for the rest of his career. In 1981, the University of Liverpool honoured him by appointing him as Director of Studies in Behavioural Paediatrics, a position he occupied until his early retirement in 1983.

Philip was a prolific writer, the author of two books and more than 50 papers detailing his research into the psychosomatic correlation in childhood asthma, diabetes, cystic fibrosis, end-stage renal disease and ulcerative colitis.

'PP', as he was affectionately known, was a superb lecturer. His incisive wit, scholarship and mastery of the English language held captive many an audience, and provided the stimulus for many of us to take up careers in child and adolescent psychiatry. In medicine he favoured the 
'apprenticeship model' of training, emphasising the physician's total commitment and responsibility towards his patient. Individuals from other disciplines will also have cause to remember PP with gratitude and affection, particularly those psychiatric social workers who trained with him.

Philip acquired a national and international reputation in his chosen area of study, visiting America, Canada, Australia, Norway and Israel, as guest Professor. In spite of many invitations to take up positions overseas, Philip remained loyal to Merseyside and stayed with us until his retirement in 1983. He never stopped working, however; when he moved to Essex he continued his research interest in cystic fibrosis, working at the Brompton Hospital.

He was very much a family man who, in the rare moments which work afforded to him, loved to practise his violin or, together with his wife, Hilda, attend a concert at the Royal Liverpool Philharmonic Hall. Hilda is herself an accomplished artist, and PP took great pleasure in displaying her paintings in his room at the Children's Hospital. He was also very proud and pleased to acknowledge the success of his children-David is a dental surgeon; Gillian a psychologist, and Stuart a doctor.

Tudno Gwynne Whluams, formerly Physician Superintendent, North Wales Hospital, Denbigh.

Dr Gwynne Williams, for two decades a leading figure in psychiatry in Wales, died on 30 November 1986 at the age of 71.

Gwynne Williams was born in Llandudno, North Wales. A son of the manse, he gained a scholarship to Caterham School, entered the Middlesex Hospital Medical School and graduated MB BS in 1938. After house appointments in and around London, he served in the Royal Navy from 1940 to 1946 where, tutored and influenced by Desmond Curran, he became a neuropsychiatric specialist. After the war he continued his training at Queen's Square and then at
Mapperley Hospital, obtaining the DPM and his London MD.

In 1948, with many paths open to him, he returned to the native area he loved. His appointment as consultant psychiatrist to the North Wales Hospital, Denbigh marked the beginning of 33 years in which he played a leading role in developing psychiatric services throughout the hospital's huge catchment area. For 16 years he was its physician superintendent. With his natural gifts of leadership and wisdom, and with his deep feeling for North Wales and its people, Gwynne Williams oversaw the transition of the hospital from a Victorian county asylum to the centre of a modern, clinical psychiatric service. He was acutely aware of the vulnerability of remote mental hospitals and of the effects, good and bad, that a physician superintendent may have upon them. He was successful in achieving change because colleagues were quick to recognise his abilities and had absolute confidence in his judgement and integrity.

He knew that psychiatry had to fight its corner and with his wide knowledge and his organisational skills he became an influential and respected ambassador for the speciality. He served with distinction on the Welsh Hospital Board until its dissolution, becoming vice-chairman of its planning committee. In the College he represented Wales on Council, was an examiner for the membership and served on the Public Policy Committee.

He accepted administrative work as inevitable but was never happier than when exercising his considerable clinical acumen. He had a quiet, perceptive and sensitive manner and his clinical opinions were in demand by general practitioners and by consultant colleagues in and outside psychiatry. He was a doctor's doctor to whom many medical men, and their families, had reason to be grateful. Gwynne Williams had an enviable reputation as a distinguished psychiatrist. Those who had the pleasure of working with him also remember with great affection a man without pomp or pretension who was a unique source of wisdom and guidance.

\section{MRCPsych Examination Courses}

A 7-day residential revision course in two streams for the MRCPsych Part I and Membership examinations will be held at the University of Surrey, Guildford from 9-16 September 1987. In addition to lectures and seminars, each stream programme includes mock clinical/viva voce and written papers with confidential assessment. Fees: residential $£ 363$; non-residential $£ 252$ (including meals). Applications and enquiries: Mrs 0 . Wellden, Belmont Postgraduate Psychiatric Centre, 6 Homeland Drive, Sutton, Surrey SM2 SLY (telephone 01643 3322, extension 282).

MRCPsych clinical examinations: Practice is afforded to candidates, in the presentation of cases under examination conditions, between 8.15 and 9.00 a.m. on Thursdays in the Department of Psychiatry at Epsom District Hospital. There is no fee. Details: Dr L. Hemsi, Epsom District Hospital, Dorking Road, Epsom, Surrey KT19 7EG (telephone Epsom 26100, extension 512).

The Institute of Child Health (University of London) will hold an intensive $1 \frac{1}{2}$ day course for doctors sitting the MRCPsych Part II examination on 2-3 October 1987. Abstracts provided for revision purposes. Fee $£ 45$. Further details: Teaching Office, Institute of Child Health, 30 Guilford Street, London WCIN IEH (telephone 01829 8692). 